\title{
Expression of platelet-activating factor receptor in the hamster oviduct: localization to the endosalpinx
}

\author{
L. A. Velasquez ${ }^{1}$, S. R. Ojeda ${ }^{2}$ and H. B. Croxatto ${ }^{1}$ \\ ${ }^{1}$ Unidad de Reproducción y Desarrollo, Facultad de Ciencias Biológicas, Pontificia Universidad Católica de \\ Chile, Santiago, Chile; and ${ }^{2}$ Division of Neuroscience, Oregon Regional Primate Research Center, \\ Beaverton, OR 97006, USA
}

\begin{abstract}
Platelet-activating factor (PAF) is a lipid mediator that has a range of biological effects on various cells and tissues. PAF-like activity has been detected in the spent media of two-cell to morula stage hamster embryos, leading to the suggestion that PAF may be the embryonic signal that hastens embryo transport to the uterus in this species. The present study was undertaken to examine whether the PAF receptor (PAFr) gene is expressed in hamster oviduct, and to identify the cell types in which the gene is expressed. DNA fragments complementary to the coding region of mRNA encoding hamster PAFr were cloned by reverse transcription-polymerase chain reaction (RT-PCR), identified by sequencing and used to prepare hamster specific cRNA probes. The presence of mRNA transcripts encoding the PAFr receptor in the oviduct was investigated by subjecting oviduct mRNA to RT-PCR. Southern blot analysis of the RT-PCR products verified the identity of the presumptive PAFr cDNAs. The cloned cDNA fragment of hamster PAFr was found to be highly conserved with respect to the receptor of other species, having $94.3 \%$ sequence similarity to the rat PAFr receptor. Hybridization histochemistry demonstrated that PAFr is expressed in the subepithelial cells and occasionally in the epithelium. In conclusion, expression of PAFr in the hamster oviduct is compatible with the proposed paracrine role of early embryo-derived PAF.
\end{abstract}

\section{Introduction}

Although there is ample evidence that ovarian hormones regulate ovum transport in some mammals (Croxatto et al., 1991), marked differences in the oviductal transport of embryos and oocytes in mares, bats, mice and hamsters (Rasweiler, 1979; Ortiz et al., 1986; Croxatto et al., 1991; Weber et al., 1991a, b) suggest that the conceptus may also be a source of regulatory signals in this process (Ortiz and Croxatto 1991)

Most hamster embryos enter the uterus, in mated females, by 13:00 $\mathrm{h}$ on day 3 of pregnancy, while most oocytes do so, in non-mated females, $24 \mathrm{~h}$ later (Ortiz et al., 1986). Ortiz et al. (1986) inseminated non-mated females with fertile spermatozoa in one uterine horn and infertile spermatozoa in the contralateral side to determine whether embryos are transported faster than oocytes or whether the oviduct behaves differently in mated and unmated hamsters. Thus, embryos were transported by the oviduct on one side and oocytes by the other oviduct, both sides being under equal neuroendocrine influences. Under these conditions, embryos were transported to the uterus as in mated females (Ortiz et al., 1986). Similar results were obtained when the same experimental design was carried out in hamsters made pseudopregnant by mating with vasectomized males (Ortiz and Croxatto, 1991). Furthermore,

Received 28 June 1996. hamster oocytes and embryos at day I were transferred to the oviducts of rats on day 1 of pregnancy; oocytes were transferred to one side and embryos to the other side. In rats, embryos normally begin to enter the uterus in the evening of day 4 of pregnancy (Fuentealba $e t$ al., 1987). However, in rats in which heterologous eggs had been transferred, more than half of the native and transferred embryos entered the uterus by early afternoon of day 4 , while almost $100 \%$ of native embryos and transferred hamster oocytes remained in the contralateral oviduct at this time (Croxatto et al., 1991). These findings led to the proposal that hamster embryos secrete a factor that acts on the oviduct to hasten their transport to the uterus (Ortiz et al., 1986; Croxatto and Ortiz, 1991).

In mares, embryos enter the uterus around day 5 of pregnancy while, in non-conceptional cycles, oocytes are retained in the oviducts. There is good evidence that prostaglandin $\mathrm{E}_{2}$ produced by the embryo on day 5 determines its transport to the uterus at that time (Weber et al., 1991a, b). Since treatment with prostaglandin synthesis inhibitors in hamsters fails to alter oviductal embryo transport (Thomas et al., 1987; Velasquez et al., 1995), prostaglandins have been excluded as mediators of embryo signalling in this species.

Subsequently in hamsters, two antagonists of plateletactivating factor (PAF, 1-O-alkyl-2-acetyl-sn-glycerol-3phosphocholine), administered systemically or locally in the periovarian sac, were shown to delay the transport of embryos, 
but not oocytes, to the uterus. Local administration of PAF also accelerates oviductal transport of oocytes and PAF-like activity is present in spent media of two-cell to morula stage hamster embryos (Velasquez et al., 1995). Therefore, it was proposed that in hamsters PAF is the embryonic signal acting on the oviduct to hasten embryo transport to the uterus.

Platelet-activating factor is a lipid mediator that possesses diverse and potent biological effects on several cells and tissues (Chao and Olson, 1993; Imaizumi et al, 1995), including a potential involvement in several reproductive processes (Harper, 1989). It is secreted from zygotes and early embryos of a variety of species, including mice, humans and sheep (O'Neill et al., 1985; Batty et al., 1991). It has been suggested that embryo-derived PAF decreases vascular perfusion and capillary permeability in the endosalpinx of the mouse (Stein and O'Neill, 1994). The hypothesis that PAF is the embryonic signal controlling oviductal embryo transport in hamsters (Velasquez et al., 1995) presumes that PAF receptors (PAFr) are expressed in hamster oviductal cells in close vicinity to the embryos. This assumption was tested by using the highly sensitive technique of reverse transcription-polymerase chain reaction (RT-PCR) to determine whether and where PAFr gene expression occurs in the hamster oviduct. Complementary DNA fragments derived from the coding regions of hamster mRNA encoding PAFr were isolated by RT-PCR, cloned and characterized by sequencing before use as templates to prepare RNA probes. These hamster-specific probes were used for hybridization histochemistry.

\section{Materials and Methods}

\section{Animals}

Female golden hamsters of 100-150 g body mass were used. The animals were kept with artificial illumination from 06:00 to 21:00 $\mathrm{h}$ and under controlled temperature $\left(21-24^{\circ} \mathrm{C}\right)$. Water and pelleted food were supplied ad libitum. Females were examined daily for appearance of postoestrous discharge (day I of the oestrous cycle), and were used after exhibiting at least two regular 4 day cycles. The females were caged overnight with a male of proven fertility, on the evening of day 4 of the cycle. Day I of pregnancy was defined as the day after spermatozoa were present in the vaginal smear. Pregnant females were killed by excess ether inhalation at 17:00 $\mathrm{h}$ on day 3 and cyclic females were killed at 17:00 h on day 4 , since the mean number of oviductal ova in pregnant females decreases progressively from $10: 00 \mathrm{~h}$ to $17: 00 \mathrm{~h}$ on day 3 in contrast to cyclic animals in which most ova are still present in the oviduct up to $10: 00 \mathrm{~h}$ on day 4 (Ortiz et al., 1986). The tissues were dissected clean of fat and were immediately frozen on dry ice and stored at $-80^{\circ} \mathrm{C}$ until RNA extraction.

\section{RNA preparation}

Total RNA was prepared from oviduct, uterus, ovary, spleen and adrenal gland by the acid-phenol extraction method (Chomczynski and Sacchi, 1987) modified by Ojeda et al. (1990).

\section{Generation of hamster specific probes}

All the oligodeoxynucleotides used were synthesized in an Applied Biosystems 391 DNA synthesizer (Foster, CA). cDNA from cellular polyadenylated mRNAs was generated by using an oligodeoxynucleotide $\mathrm{dT}$ primer for reverse transcription (RT) of total RNA from both ovary and lung. Taking advantage of the sequence similarity between human, guinea-pig and rat mRNA encoding PAFr (Bito et al., 1994), one set of gene-specific oligodeoxynucleotide primers was synthesized. A $368 \mathrm{bp}$ cDNA fragment spanning the entire hamster PAFr coding region sequence was amplified using a sense oligodeoxynucleotide (5'-TGGACTCCACCAACGTAGTG-3') corresponding to nucleotides (nt) 581-600 in the guinea-pig cDNA sequence encoding PAFr, and an antisense oligodeoxynucleotide ( $5^{\prime}$-TGACCTGATGTGCATCATTAAT-3') complementary to the downstream sequence between nucleotides 928 and 949. An antisense internal oligodeoxynucleotide ( $5^{\prime}$-CTGGTCATCATCCACACGCT-3') complementary to the sequence between nucleotides 736 and 755 was synthesized and used for Southern blot analysis to verify the identity of the PCR products.

\section{RT-PCR procedures}

Reverse transcription was carried out for $2 \mathrm{~h}$ at $37^{\circ} \mathrm{C}$ in a total volume of $20 \mu \mathrm{l}$. Each reaction mixture contained $5 \mu \mathrm{g}$ of total RNA from hamster ovary or lung, $1 \times R T$ buffer $\left(50 \mathrm{mmol}\right.$ Tris- $\mathrm{HCl} \mathrm{^{-1 }}, \mathrm{pH} 8.3 ; 75 \mathrm{mmol} \mathrm{KCl} \mathrm{l}{ }^{-1} ; 3 \mathrm{mmol}$ $\left.\mathrm{MgCl}_{2} \mathrm{I}^{-1}\right), 0.01 \mathrm{~mol}$ dithiothreitol $1^{-1}, 0.5 \mathrm{mmol}$ of each dNTP I ${ }^{-1}, 20 \mathrm{U}$ of RNasin, $25 \mathrm{pmol}$ of oligo(dt) primer and $200 \mathrm{U}$ of Moloney murine leukemia virus reverse transcriptase (Life Technologies Inc., Gaithersburg, MD). Reaction tubes were incubated at $42^{\circ} \mathrm{C}$ for $60 \mathrm{~min}$. At the end of the incubation period, the reaction was stopped by heating at $90^{\circ} \mathrm{C}$ for $5 \mathrm{~min}$.

Each PCR amplification was performed in $75 \mu$ f final reaction volume containing the $\mathrm{CDNA}$ mixture diluted with the reaction buffer $(\times 10)$ to a final composition of: $10 \mathrm{mmol}$ Tris $-\mathrm{HCl} \mathrm{l}^{-1}$, $\mathrm{pH} 8.3,50 \mathrm{mmol} \mathrm{KCl} 1^{-1}, 1.5 \mathrm{mmol} \mathrm{MgCl}_{2} \mathrm{l}^{-1}$ and $100 \mu \mathrm{mol}$ dNTPs $1^{-1}, 2.5 \mathrm{U}$ of Taq polymerase and $55 \mathrm{pmol}$ of each primer. The tubes were placed in the Programmed Tempcontrol system which was programmed as follows: (a) incubation at $95^{\circ} \mathrm{C}$ for 4 min (initial melt); (b) 35 cycles of the following sequential steps: $94^{\circ} \mathrm{C}$ for $15 \mathrm{~s} \mathrm{(melt);} 55^{\circ} \mathrm{C}$ for $1 \mathrm{~min}$ (anneal); $72^{\circ} \mathrm{C}$ for $2 \mathrm{~min}$ (extend). (c) Finally, incubation at $72^{\circ} \mathrm{C}$ for $7 \mathrm{~min}$ (final extention).

\section{Southern blot analysis and sequencing of RT-PCR-generated hamster $C D N A$ encoding platelet-activating factor receptor}

The identity of the PCR products was verified by cloning them into riboprobe vector pGEM-T (Promega Biotech) that contained T7 and Sp6 RNA polymerase promoters flanking a multiple cloning region within the $\alpha$-peptide coding region of the enzyme $\beta$-galactosidase. insertional inactivation of the $\alpha$-peptide allowed recombinant clones to be directly identified by colour screen on X-Gal plates; positive bacterial colonies were grown and the plasmid was isolated. The plasmid was cut with the restriction enzymes Nco I and Not I, and the 


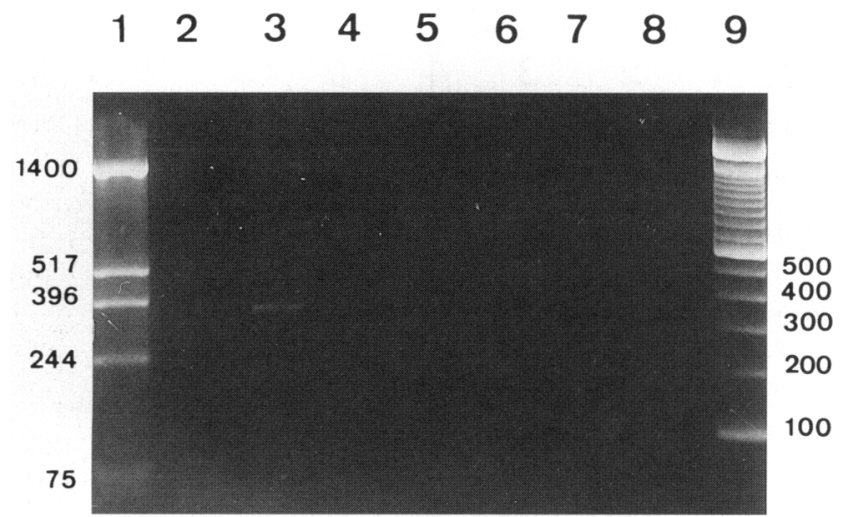

Fig. 1. Ethidium bromide-staining of RT-PCR products obtained using primers complementary to the conserved regions of guinea-pig and human mRNA encoding platelet-activating factor. Lane 2, RT-PCR control, no RNA added to reverse transcription; lane 3, ovary; lanes $4-5$, lung; lanes $6-8$, liver; lanes $I$ and 9. DNA markers.

fragments were separated by gel electrophoresis in a $2 \%$ agarose gel. After transfer to Nytran membranes (Stratagene, La Jolla, CA) and cross-linking of the DNA (120000 $\mu$ for 35 s), Southern blot analysis (Ausubel et al., 1992), to verify the identity of the PCR products, was performed with $5^{\prime}$-end $\gamma$ $\left[{ }^{32} \mathrm{P}\right] \mathrm{dATP}-\mathrm{labelled}$ antisense internal oligodeoxynucleotide probes, using T4 polynucleotide kinase (Life Technologies Inc.).
The positive clones were sequenced by the dideoxynucleotide termination method of Sanger et al. (1977), using Sequenase T7 DNA polymerase and kit (Sequenase Version 2.0; USB, Cleveland, $\mathrm{OH})$.

\section{Probe preparation}

The plasmid containing the cDNA encoding PAFr was linearized for the synthesis in vitro of RNA. Single stranded sense and antisense RNA probes $\left(\left[{ }^{35} \mathrm{~S}\right] \mathrm{UTP}\right.$-label) were synthesized using the polymerases T7 or Sp6 (Life Technologies Inc.) to direct the transcription.

\section{Hybridization histochemistry}

The procedure used was based on that of Simmons et al. (1989), with some modifications (Junier et al., 1991; Ma et al., 1992). The oviducts of pregnant females on day 3 and cyclic females on day 4 (as control) were fixed overnight in $4 \%(\mathrm{w} / \mathrm{v})$ paraformaldehyde in borate buffer $(\mathrm{pH} 9.5)$; this was followed by overnight incubation with PBS, containing $10 \%(\mathrm{w} / \mathrm{v})$ sucrose. The oviducts were then blocked, frozen on dry ice, and stored at $-85^{\circ} \mathrm{C}$ until sectioning. A sliding microtome was used to prepare sections $20 \mu \mathrm{m}$ in thickness, which were adhered to polylysine-coated slides, and dried overnight under vacuum before hybridization. The sections were overlaid with $70 \mu \mathrm{l}$ hybridization buffer, which consisted of $50 \%(\mathrm{w} / \mathrm{v})$ formamide, $0.25 \mathrm{~mol} \mathrm{NaCl} \mathrm{l}^{-1}, 10 \mathrm{mmol} \mathrm{EDTA} \mathrm{l}^{-1}, 10 \mathrm{mmol}$
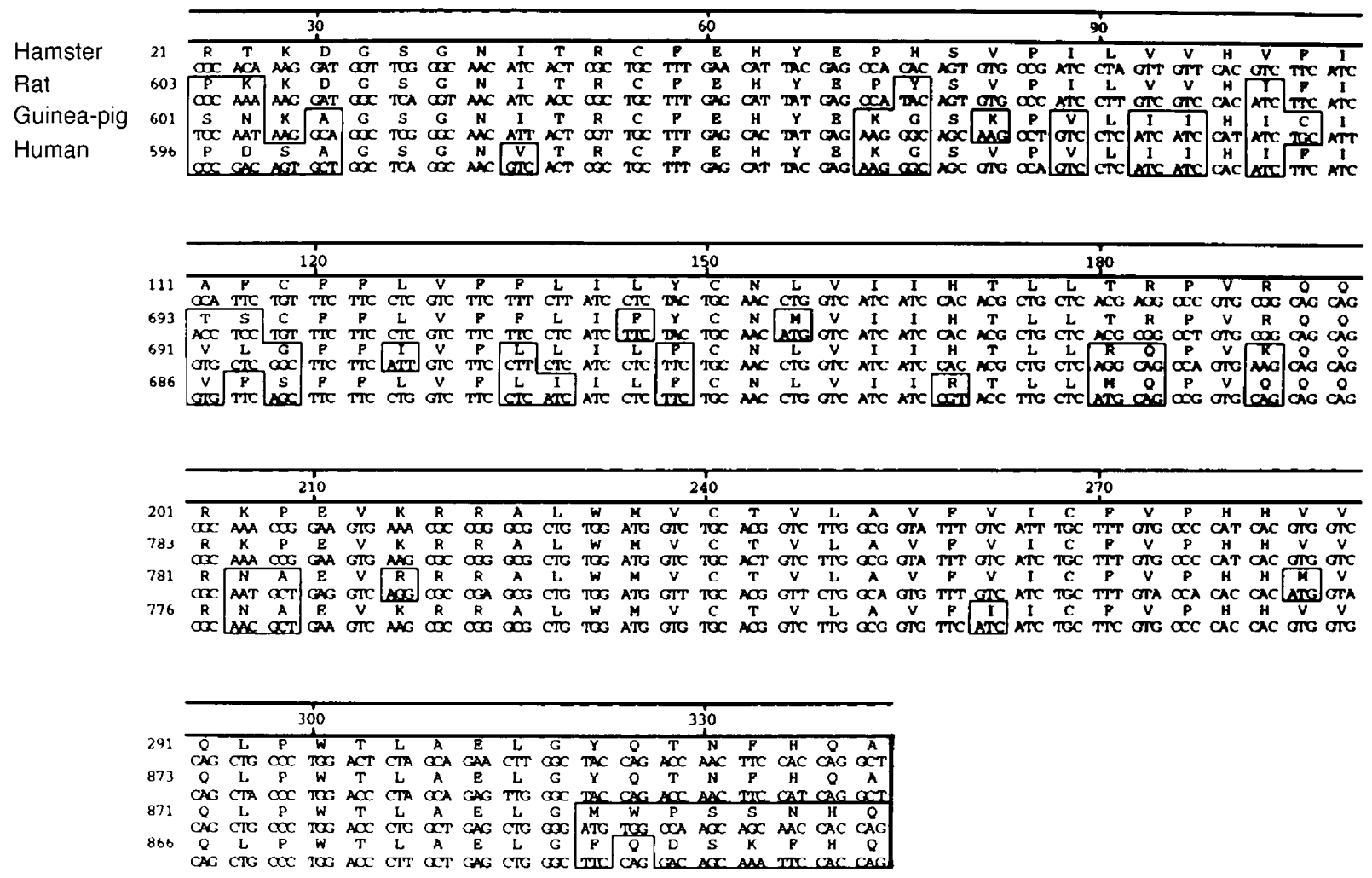

Fig. 2. Deduced amino acid sequence of a hamster cDNA encoding platelet-activating factor receptor (PAFr) isolated from hamster ovary by RT-PCR. The corresponding rat, guinea-pig and human sequences of cDNA encoding PAFr are depicted for comparative purposes. The boxed residues differ from hamster PAFr. 
Tris ( $\mathrm{pH} 8.0$ ), and $2 \times$ Denhardt's solution (Ficoll, polyvinyl pyrrolidone and BSA at $0.04 \%(\mathrm{w} / \mathrm{v})$ each) containing $1 \times 10^{7}$ c.p.m. $\left[{ }^{35}\right.$ S]UTP-labelled PAFr cRNA probe $\mathrm{ml}^{-1}$. The hybridization was carried out for $18-20 \mathrm{~h}$ at $55^{\circ} \mathrm{C}$ and was followed by several washings to a final stringency of $0.1 \times \mathrm{SSC}$ at $65^{\circ} \mathrm{C}$ (Simmons et al., 1989). After washing, the sections were defatted, dipped in NTB-2 emulsion, and developed after exposure for 4 weeks. Controls were hybridized to a sense RNA probe, synthesized from the same template used to produce the antisense probe but using the corresponding polymerase for directing transcription of sense RNA.

\section{Results}

Cloning of hamster cDNA encoding platelet-activating factor receptor

A PAFr gene fragment (Fig. 1) was amplified from ovarian and lung mRNA-derived $\mathrm{CDNA}$ and directly cloned into pGEM-T cloning vector. Sequencing of the PCR product demonstrated that both fragments had the same sequence.

\section{Comparison of hamster, rat and guinea-pig sequences of $c D N A$ encoding platelet-activating factor receptor}

Sequencing of the hamster PAFr cDNA obtained by RT - PCR revealed that the coding region of hamster PAFr has $89.6 \%$ similarity at the nucleotide level and $94.3 \%$ sequence homology at the amino acid level to the rat sequence (Fig. 2). The hamster PAFr has only eight amino acid substitutions with respect to the rat sequence, which further confirms its conserved nature.

\section{Detection of platelet-activating factor gene expression in hamster} oviduct by RT-PCR/Southern blot analysis

RT-PCR was performed with oviductal and uterine RNA using the same set of primers, and the subsequent Southern blots of the RT-PCR products were subjected to hybridization with an oligonucleotide probe specific to an internal sequence of the hamster cDNA encoding PAFr. This approach was used and RT-PCR was performed on RNA from five animals. The ethidium-stained gel and subsequent Southern blots of these fractions are shown (Fig. 3). A band of similar size (368 bp) to that seen in the control (uterus, lane 8) was observed in the oviductal samples upon ethidium bromide staining of the RT-PCR products (Fig. 3a). The PCR control, which consisted of a fraction devoid of RNA, was negative. Southern blots of this gel hybridized to a hamster PAFr-specific oligonucleotide probe demonstrated that in all five animals a cDNA encoding PAFr had been amplified (Fig. 3b).

Identification of the cell type(s) expressing the platelet-activating factor gene in the hamster oviduct

Hybridization histochemistry, using an $\alpha\left[{ }^{35}\right.$ S]UTP-labelled antisense RNA probe transcribed from the cDNA encoding PAFr cloned by RT-PCR and complementary to the coding (a)

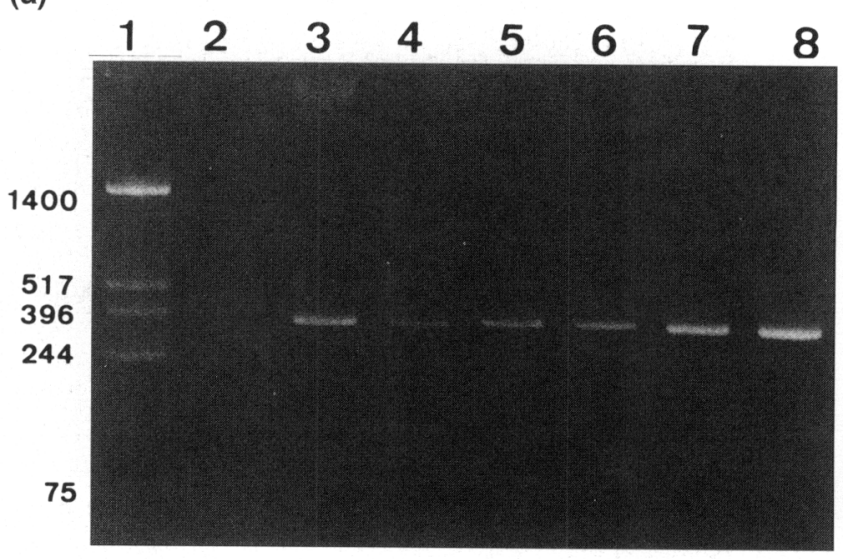

(b)

1400 396

75

Fig. 3. RT-PCR/Southern blot analysis of PCR products amplified from oviducts of hamsters using platelet-activating factor receptor (PAFr) gene primers complementary to the guinea-pig and human PAFr mRNA sequences. (a) ethidium bromide staining of RT-PCR products derived from total RNA of oviduct (lanes 3-7) and uterus (positive control, lane 8 ). The PCR control had no RNA added to the RT reaction (lane 2). Lane 1, DNA marker. (b) Shows that the PCR products contain the sequence of DNA encoding PAFr as they hybridize with a hamster-specific oligonucleotide that recognizes a sequence contained within the amplified PCR fragment.

regions of mRNA encoding PAFr, showed that a major site of PAFr gene expression is the subepithelial cells of the mucosal folds (Fig. $4 \mathrm{a}-\mathrm{c}$ ). Hybridization to the epithelium was also observed but was much less prominent (data not shown). No specific hybridization signal was detected in the myosalpinx or in sections hybridized to sense mRNA probes that show only thionin autofluorescence (Fig. 4d). A similar distribution of hybridization of mRNA encoding PAFr was found in the oviducts of cyclic animals (data not shown).

\section{Discussion}

We have proposed that PAF is the embryonic signal that controls oviductal transport of embryos in hamsters (Velasquez et al., 1995). This hypothesis presumes the presence of PAFr in oviductal cells located in the vicinity of the embryos. In the present study, we demonstrate that mRNA encoding PAFr is expressed in hamster oviductal cells. A previous ligand binding study in rabbits showed the presence of the receptor protein in 

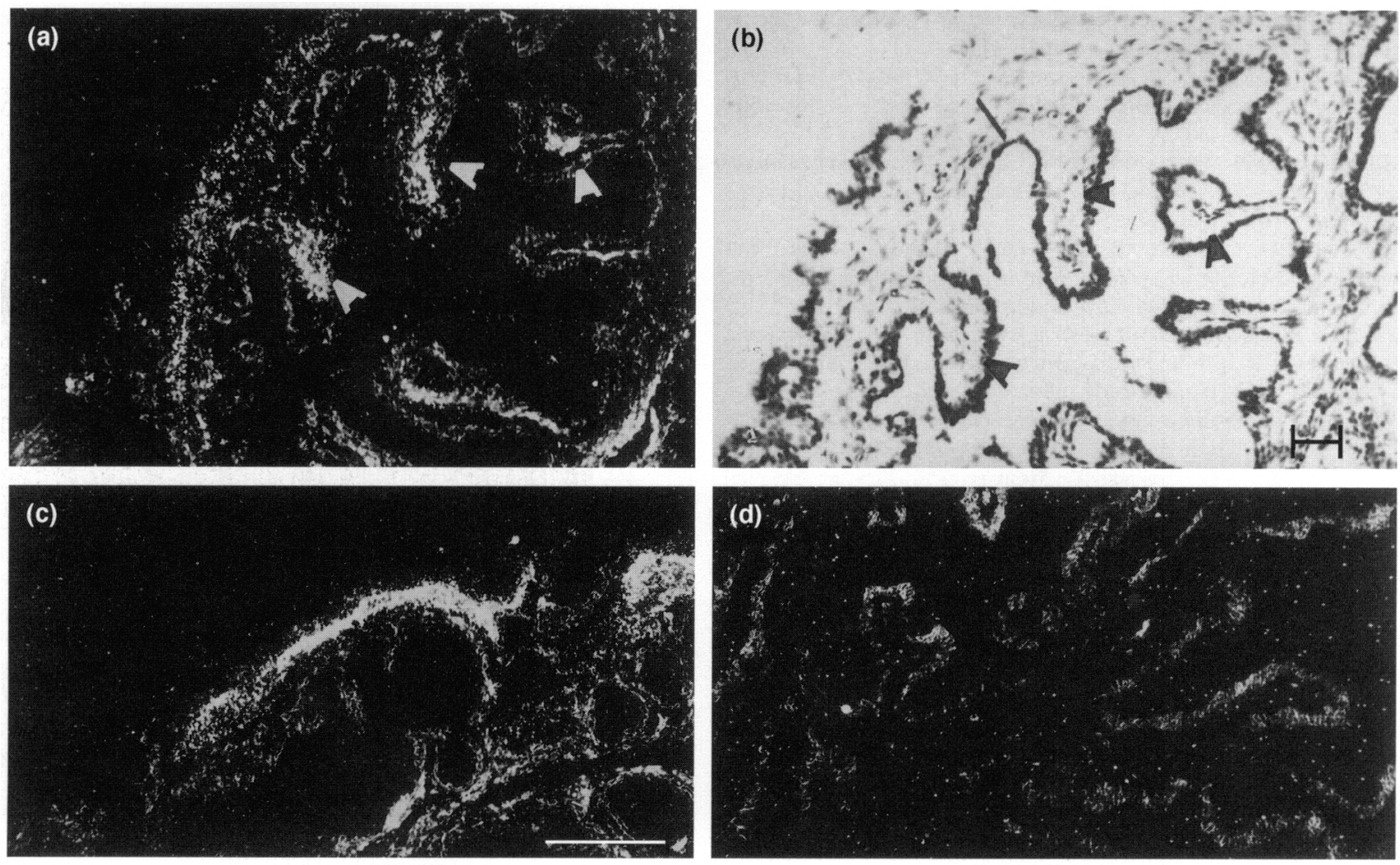

Fig. 4. Hybridization histochemistry showing the tissue distribution of mRNA encoding platelet-activating factor receptor (PAFr) in the hamster oviduct. (a) Hybridization of the PAFr cRNA probe to subepithelial cells (arrowheads) located in mucosa folds. (b) Thionin staining of the same section shown in the histological aspect of the oviduct at this level, with arrowheads pointing to the subepithelial cells that express the PAFr gene. (c) A further example of hybridization in the endosalpinx cells. (d) Section showing no specific hybridization to a sense RNA probe. Scale bar represents $200 \mu \mathrm{m}$.

the oviduct (Yang et al., 1992). Expression of mRNA encoding PAFr was restricted to the endosalpinx and was most prominent in the subepithelial cells located in the mucosal folds that protrude into the lumen of the oviduct. This localization is most favourable for a paracrine function of embryo-derived PAF during oviductal embryo transport.

It is important to consider that the site of action of PAF is the cells located in the endosalpinx rather than the myosalpinx and that, at least in rats, accelerated embryo transport is associated with increased frequency of myosalpinx contractions (Moore and Croxatto, 1988). If PAF is the embryonic signal that hastens embryo transport to the uterus in hamsters and this is achieved as in rats, it is possible that the endosalpinx is a relay station between the embryo and the smooth muscle cells, unless the driving force is the ciliary beat.

Hamster embryos are transported to the uterus faster than oocytes (Ortiz et al., 1986). Administration of PAF to cyclic hamsters hastens transport of their oocytes, implying that their oviducts express PAF receptor. The slower transport of oocytes in cyclic hamsters may be associated with less or no PAF production, fewer PAF receptors in the oviduct, or both. The first possibility is likely since acetyltransferase, the final enzyme in the membrane remodelling pathway for PAF biosynthesis, has lower specific activity in mouse oocytes compared with embryos (Wells and O'Neil, 1994). The second possibility is supported by the finding of a fivefold higher concentration of PAF binding sites in rabbit oviductal membranes obtained on day 3, near the end of the oviductal phase of transport, compared with that obtained on day 6 of pregnancy (Yang et al., 1992). This differential level of expression suggests that pregnancy-associated factors, such as coitusinduced neuroendocrine changes or embryonic signals, control PAFr concentrations in the oviduct.

The results of this study are consistent with the view that PAF of embryonic origin is the signal used by hamster embryos to control their transport to the uterus (Velasquez et al., 1995). PAF is secreted from zygotes of a variety of species, including mice, humans and sheep (O'Neill et al., 1985; Moore and Croxatto, 1988; Batty et al., 1991). It is possible that PAF may also play a role in the control of embryo transport in these species.

The authors thank the staff of the Division of Neurosciences of the Oregon Primate Research Center for expert technical assistance. This work was supported by FONDECYT 2950083, Rockefeller Foundation grant number 94025 number 14, Ernst Schering Research Foundation and Instituto Chileno de Medicina Reproductiva.

\section{References}

Ausubel FM, Brent R, Kingston RE, Moore DD, Seidman JG, Smith JA and Struhl K (1992) Current Protocols in Moleculir Biology Vol I. Ch 2.1.I-2.7.8. John Wiley and Sons, New York

Batty KM, Ammit AJ, O'Neill C and Evans G (1991) Production of plateletactivating factor by pre-implantation sheep embryo Journul of Reproduction and Fertility 93 507-512

Bito H, Honda Z, Nakamura M and Shimizu T (1994) Cloning, expression and tissue distribution of rat platelet-activating factor-receptor CDNA Europerm Joumal of Biochemistry $221211-218$ 
Chao W and Olson S (1993) Platelet-activating factor: receptors and signal transduction Biochemical Journal $292617-629$

Chomczynki P and Sacchi N (1987) Single step method of RNA isolation by acid guanidium thiocyanate-phenol-cloroform extraction Analytical Biochemistry 162 156-159

Croxatto HB and Ortiz ME (1991) Oviductal recognition of embryonic signals. In Uterine and Embryonic Factors in Early Pregnancy pP 1-5 Eds JF Straus III and CR Lyttle. Plenum Press, New York

Croxatto, HB, Ortiz ME, Forcelledo ML, Fuentealba B, Moore G, Moran F and Cardenas H (1991) Hormonal control of ovum transport throught the rat oviduct Archivos de Biologia y Medicina Experimentales 24 403-410

Fuentealba B, Nieto M and Croxatto HB (1987) Ovum transport in pregnant rats is little affected by RU486 and exogenous progesterone as compared to cycling rats Biology of Reproduction 37 768-774

Harper, MJK (1989) Platelet-activating factor: a paracrine factor in preimplantation stages of reproduction? Biology of Reproduction 40 907-913

Imaizumi TA, Stafforini DM, Yamada Y, Mcintyre TM, Prescott SM and Zimmerman GA (1995) Platelet-activating factor: a mediator for clinicians Journal of Internal Medicine 238 5-20

Junier M, Ma YJ, Costa ME, Hoffman G, Hill DF and Ojeda SR (I99I) Transforming growth factor alpha (TGF $\alpha$ ) contributes to the mechanism by which hypothalamic injury induces precocious puberty Proceedings of National Academy Sciences USA 88 9743-9747

Ma YJ, Junier M, Costa M and Ojeda SR (1992) Transforming growth factor alpha (TGF $\alpha$ ) gene expression in the hypotalamus is developmentally regulated and linked to sexual maturation Neuron $9657-670$

Moore GD and Croxatto HB (1988) Synthetic microspheres transferred to the rat oviduct on day 1 of pregnancy mimic the transport of native ova Journal of Reproduction and Fertility $\mathbf{8 2} 735-742$

O'Neill C, Gidley-Baird AA, Pike IL, Porter RN, Sinosich MJ and Saunders DM (1985) Maternal blood platelet physiology and luteal phase endocrinology as means of monitoring pre- and postimplantation embryo viability following in vitro fertilization Journal of In Vitro Fertilization and Embryo Transfer 2 $87-93$

Ojeda SR, Hill DF and Katz, KH (1990) The genes encoding nerve growth factor and its receptor are expressed in developing female rat hypothalamus Molecular Brain Research 9 47-55

Ortiz ME and Croxatto HB (1991) Differential transport of fertilized and unfertilized eggs Archivos de Biologia y Medicina Experimentales 24 403-410
Ortiz ME, Bedregal P, Carvajal MI and Croxatto HB (1986) Fertilized and unfertilized ova are transported at different rates by hamster oviduct Biology of Reproduction 34 777-781

Rasweiler JJ (1979) Differential transport of embryos and degenerating ova by oviducts of long-tongue bat, Glossophaga soricina. Journal of Reproduction and Fertility $55 \quad 329-334$

Sanger F, Nicklen S and Coulson AR (1977) DNA sequencing with chainterminating inhibitors Proceedings of National Academy Sciences USA $\mathbf{7 4}$ 5463-5467

Simmons DM, Arriza JL and Swanson (1989) A complete protocol for in situ hybridization of messenger RNAs in brain and other tissues with radiolabeled single-stranded RNA probes Journal of Histotechnology 12 169-181

Stein BA and O'Neill C (1994) Morphometric evidence of changes in the vasculature of the uterine tube of mice induced by the 2-cell embryo on the second day of pregnancy Journal Anatomy 185 397-403

Thomas CM, Bastiaans LA and Rolland MD (1987) Effects of prostaglandin F indomethacin, and estradiol on ovum transport and pregnancy in the golden hamster Biology of Reproduction $23687-698$

Velasquez LA, Aguilera JG and Croxatto HB (1995) Possible role of platelet activating factor (PAF) in embryonic signalling during oviductal transport in the hamster Biology of Reproduction 52 1302-1306

Weber JA, Freeman DA, Vanderwall DK and Woods GL (1991a) Prostaglandin $E_{2}$ hastens oviductal transport of equine embryos. Biology of Reproduction $\mathbf{4 5}$ 544-546

Weber JA, Freeman DA, Vanderwall DK, Woods GL (1991b) Prostaglandin E secretion by oviductal transport-stages equine embryos Biology of Reproduction 45 532-535

Wells XE and O'Neill C (1994) Detection and preliminary characterization of two enzymes involved in biosynthesis of platelet-activating factor in mouse oocytes, zygotes and preimplantation embryos: dithiothreitol-insensitive cydinediphosphocholine: 1-O-alkyl-2-acetyl-sn-glycerol cholinephosphotransferase and acetyl-coenzime A:1-O-alkyl-2-lyso-sn-glycero-3phosphocholine acetyltransferase Journal of Reproduction and Fertility 101 385-391

Yang YQ, Kudolo GB and Harper MJK (1992) Binding of platelet-activating factor to oviductal membranes during early pregnancy in the rabbit Journal of Lipid Mediators 5 77-96 